Irena Selišnik ${ }^{*}$

\title{
Skrb v službi vojne: bolniške strežnice na Kranjskem
}

\begin{abstract}
IZVLE ČEK
Že pred začetkom prve svetovne vojne je v Avstriji tekla razprava, ali bi bilo primerno pri oskrbi ranjencev vključiti bolniške sestre (v primeru večjega vojaškega obračuna, hujših naravnih katastrof ali epidemij), po izbrubu vojne pa so avstrijske oblasti spodbudile profesionalizacijo poklica medicinske strežnice oziroma medicinske sestre. Z zakonodajo so določile posebne pogoje za šolanje ter odprle prve šole in strežniške tečaje v lokalnih bolnicah. Pri tem ni bila Kranjska nobena izjema. Rdeči križ je organiziral tečaje za strežnice, katerim so po zaposlitvi obljubili plačo, pokojnino in možnost dopusta. Avstrijska propaganda je "vojaške sestre upodabljala kot junakinje in vsaj del javnosti jih je dojemal kot poosebitev materinske skrbi in ljubezni, ki jih je postavljala ob bok vojakom - herojem. Toda "vojne sestre" so predstavljale tudi moderno žensko, ki se je umaknila nadzoru družbe in odšla nevarnosti na bojišču naproti. V javnosti pa so se pojavljali dvomi $v$ njihovo moralnost, saj naj bi imele na fronti neposredne stike z vojaki in bi bile zlasti blizu zdravnikov. S svojo prisotnostjo so posegle v dihotomijo javnolfronta-zasebno/zaledje. V podobi bolniške sestre se tako najbolje razkrijejo nelagodna razmerja med razumevanjem vojne in žensk ter hitro spreminjajoče se vrednotne norme v času vojne.
\end{abstract}

Ključne besede: bolniške sestre, strežnice, prva svetovna vojna, ženske, poklic, morala

\section{ABSTRACT}

\section{HEALTH CARE IN THE SERVICE OF WAR: WAR NURSES IN CARNIOLA}

Even before World War I an ongoing discussion took place in Austria whether medical nurses should be mobilised to take care for wounded soldiers in case of extensive military conflict, natural disasters or epidemics. After the outbreak of the Great War the Austrian authorities encouraged the professionalisation of nursing, and especially women were invited to join. Special conditions for schooling were enacted and the first courses were opened at local hospitals. In the Austrian Monarchy, Carniola was no exception. The Red Cross organised special courses for nurses with the promise of salary, retirement benefits and possibility of vacation. Austrian propaganda portrayed war nurses as heroines, and at least part of the public perceived them as a personification of motherly care and love which could be compared with the sacrifices of the soldiers. However, war nurses also represented modern women who successfully avoided social control and headed towards imminent danger in the battlefield. In the public doubts about their morality emerged, as nurses had

* dr., docentka, Filozofska fakulteta, Univerza v Ljubljani, Aškerčeva 2, SI-1000 Ljubljana, Selisnik2@siol.net 
direct contact with soldiers and were especially close to doctors. With their presence they invaded the dichotomy between public/battlefront-private/home front. The image of war nurses clearly reveals the awkward relationships between the attitudes to war and women as well as the rapidly changing values in times of war.

Keywords: nurses, care attendants, World War I, women, profession, morality

\section{Uvod}

$\mathrm{Na}$ Slovenskem dojemanje prve svetovne vojne zaznamujejo spomini vojakov iz bojne črte ali njihove izkušnje v ujetništvu. Krutost vojne naj bi bila povsem razumljena in izkušena šele $\mathrm{v}$ neposrednem spopadu, ko sta smrt ali poškodba postali $\mathrm{v}$ mislih stalni spremljevalki med predahi bitk in realno dejstvo med njimi. Toda $s$ posledicami bojne vihre še zdaleč niso bili soočeni le vojaki. Sredi strahotnosti vojne so se znašle tudi bolniške sestre oziroma strežnice. Njihova izkušnja in zgodovinski spomin sta zlasti v tujini postala predmet številnih člankov, ki osvetljujejo njihovo vlogo v luči vojne propagande, morale in profesionalizacije poklica medicinske sestre. ${ }^{1} \mathrm{O}$ njihovi izkušnji pričajo poleg literature tudi redki ohranjeni spomini, tudi takšni, ki opisujejo dogajanje na Soški fronti, vendar žal med njimi ni spominov Slovenk (oziroma doslej niso bili odkriti). ${ }^{2}$

Toda tudi prebivalke Kranjske in drugih slovenskih dežel niso bile izjeme, priključile so se množici anonimnih žensk, zaznamovanih z rdečimi križi. Njihovo izkušnjo bom predstavila $\mathrm{v}$ pričujočem članku in jo umestila $\mathrm{v}$ kontekst podobnih raziskovanj po Evropi. Poleg vseh družbenih procesov, ki so zaznamovali nastanek poklica medicinske sestre in strežnice ( $v$ času prve svetovne vojne jih je najbolje označevala beseda "vojne sestre«), in bodo v članku omenjeni, pa bom v njem obravnavala tudi nelagodje tedanje družbe, ki je zadevalo spreminjajočo se vlogo žensk (to se je najbolj odrazilo prav pri vojnih sestrah). V senci vojne propagande je splošna javnost obsojala moderno in neodvisno žensko, prav takšno žensko, kot jo je ta poklic predstavljal.

1 Christa Hämmerle, »'Mentally broken, physically a wreck...': Violence in War Accounts of Nurses in Austro-Hungarian Service, v: Gender and the First World War, ur. Christa Hämmerle, Oswald Überegger in Birgitta Bader-Zaar (Basingstoke: Palgrave Macmillan, 2014). Margaret H. Darow, "French Volunteer Nursing and the Myth of War Experiance in World War I, American Historical Review 101 (1996): 80-106. Alon Rachamimov, „'Female Generals' and 'Siberian Angels': Aristocratic Nurses and the Austro-Hungarian POW Relief, « v: Gender and War in Twentieth-Century Eastern Europe, ur. Nancy M. Wingfield in Maria Bucur (Bloomington: Indiana University Press, 2006), 23-46.

2 Marianne Jarka, Erinnerungen 1889-1934 (tipkopis). Maria Pöll Naepflin, Fortgerungen, Durchgedrungen: Ein erschütterndes Lebensbild einer Krankenschwester aus der Zeit des grossen Krieges, der Revolution und der Arbeitslosigkeit (Constance, 1933). R. M. Konrad, Scwestern als Menschen: Aus den Aufzeichnungen einer Armeeschwester (Innbruck, 1922). Eveline Hrouda, Barmherzigkeit: Als freiwillige Malteserschwester im Weltkrieg (Graz: Leykam, 1935). Dnevnik Virginie Marinaz, hranil naj bi ga Goriški arhiv v Italiji (za podatek se zahvaljujem Ani Cergol Paradiž). 
Poklic vojne sestre je pomenil pravo nasprotje vlog, ki so bile pripisane ženskam $\mathrm{v}$ predvojni družbi. V času vojne se je namreč hitro spreminjalo dojemanje žensk tudi zaradi povsem pragmatičnih potreb vojske. Avstrijska oblast je denimo sprva nameravala bolniške sestre zadržati stran od bojnih linij, naposled pa se je zaradi potreb vojaškega stroja odločila drugače. Tako so bile tudi ženske izpostavljene vojnim grozotam in travmam.

\section{Pojav vojnih sester med začudenjem in potrebo}

V začetku 19. stoletja je bila skrb za bolnike slabo plačano delo, ki so ga opravljali moški in ženske nižjega stanu. Moški so skrbeli za bolnike, ženske za bolnice. Šele v nadaljevanju stoletja je skrb postala poslanstvo žensk in tako rekoč izključno žensko delo. ${ }^{3} \mathrm{Na}$ Dunaju so se tako prve zasebne šole, ki so izobraževale za poklic medicinske sestre, pojavile že leta $1882 .{ }^{4} \mathrm{Na}$ Kranjskem so bile prve tovrstne iniciative tik pred véliko vojno v obliki tečajev za »kmetiške bolniške strežnice«, prav iz njih pa so se razvili tečaji za vojne sestre. Predvojni tečaji so nastali, ker "v tej splošni potrebi ne morejo pomagati bolnice, katerih imamo doslej primerno zelo malo, in ki sprejemajo le omejeno število bolnikov, niti ne morejo pomagati usmiljene sestre ali druge redovnice navzlic svoji požrtvovalnosti, ker je tudi njih delovanje omejeno na nekatere kraje in sloje, temveč pomagati more le naše požrtvovalno ženstvo, ako se mu nudi priložnost, da se strokovnim poukom in pod veščim vodstvom usposobi za ljudomilo delo bolniške postrežbe. " ${ }^{5}$ Od leta 1908 so izvedli kar nekaj tečajev za bolniške strežnice na podeželju (oziroma kmetiške bolniške strežnice), toda vojna je potrebo po strežniškem osebju znatno povečala. ${ }^{6}$

$\mathrm{Z}$ začetkom vojne se je proces institucionalizacije poklica medicinske sestre močno pospešil. Ministrstvo za notranje zadeve je že 25. junija 1914 izdalo ukaz, ki je postavil pravila za bolniško strežbo in preprečeval, da bi se z njo ukvarjal vsakdo. Ta dekret je najbrž temeljil tudi na izkušnji balkanskih vojn, v katerih je bilo zelo visoko število vojnih žrtev. Objavljen pravilnik je prepoznal veljavo dobro usposobljene medicinske sestre tudi na institucionalni/državni ravni, saj je država poskrbela za stalno finančno podporo tečajem in šolam. ${ }^{7} \mathrm{~V}$ njem so bila postavljena pravila za vzpostavitev šol za strežnice in tu se je že nedvoumno govorilo o učenkah ženskega spola. Te so zdaj lahko bile stare 18 let, neomadeževane, kar so dokazovale s poseb-

3 Darrow, "French Volunteer Nursing, « 273. Theodore Zeldin, An Intimate History of Humanity (London: Vintage Books, 1998), 246.

4 Franziska Salm-Reifferscheidt, „Frauen in der Kriegskrankenpflege im Ersten Weltkrieg am Beispiel der Rotkreuzschwester Marianne Jarka« (diplomsko delo, Universität Wien, 2010), 17.

5 "Poročilo o dekanskem shodu leta 1908, «Škofijski list, 1908, št. 5, 82.

6 Pred vojno je bil organiziran po en tečaj na leto, že leta 1914 so bili organizirani kar štirje. Več: Branko Šuštar, "Od strežniških tečajev do strežniške in bolničarske šole 1908-1945, « v: Šola za sestre: Zdravstveno šolstvo na Slovenskem (1753-1992), ur. Branko Šuštar (Ljubljana: Slovenski šolski muzej, 1992), 35-41.

7 Salm-Reifferscheidt, »Frauen in der Kriegskrankenpflege». 
nim potrdilom, izdanim na pristojnem okrajnem glavarstvu, ${ }^{8} s$ končano meščansko šolo in brez otrok, torej samske. $\mathrm{V}$ istem pravilniku so bili sicer omenjeni tudi moški strežniki, toda za njih so bili pogoji nekoliko drugačni, saj so ti lahko imeli družino. ${ }^{9}$

V 19. stoletju je povsod po Evropi potekal proces prestrukturiranja zdravstvenega sistema, ki ga je spremljala feminizacija skrbstvene medicinske nege, razvoj pa je vključeval tudi pomeščanjenje določenih poklicev. Vse te značilnosti lahko prepoznamo tudi v zgoraj omenjenem dekretu. Poleg velikega poudarka na učenkah lahko v njem opazimo dvig nivoja zahtevane izobrazbe. Na tečajih pred vojno so bila pričakovanja za učenke nižja, zahtevalo se je, da znajo tekoče brati in pisati in da imajo opravljeno ljudsko šolo. ${ }^{10}$ Med prvimi obiskovalkami tečaja je bilo precej deklet $s$ kmetov. ${ }^{11} \mathrm{Na}$ tečajih leta 1914 je bil pogoj opravljena meščanska šola, več učenk je prihajalo iz Ljubljane, med njimi je naraščal delež učiteljic. ${ }^{12}$ Bolniške strežnice so bile po opravljenem tečaju zavezane trem letom službovanja, tudi v vojni ali v epidemijah. Vsem, ki so se odločile za odhod na bojišče, je pripadala plača, brezplačna hrana in stanovanje ter dopust, imele naj bi tudi pokojnino. ${ }^{13}$ Diplomantke tečaja so postale pomožne strežnice, imenovali pa so jih tudi svetne strežnice, ker niso pripadale redovniškemu stanu. Vendar pa je vsaj na začetku vojne njihova obleka še precej spominjala na redovniško, saj so prav redovnice predstavljale model, po katerem naj bi se zgledovale. Tudi ljubljanski škof Anton Jeglič je v svojem dnevniku ugotavljal, $\mathrm{da}$ so "v tej obleki bolj varne pri bolnikih in imajo več veljave pri otrocih «. ${ }^{14}$

Vprašanje, koliko žensk naj bi bilo med medicinskem osebjem Avstro-Ogrske, in koliko posvetnih ter svetnih medicinskih sester je delovalo v medicinski službi v času vojne, še vedno ostaja brez natančnega odgovora, kljub temu da ti podatki obstajajo za preostale evropske države. V Nemčiji jih je bilo približno 92.000, v Franciji 63.000, v Veliki Britaniji 80.000, ${ }^{15}$ vemo pa, da je leta 1916 imelo društvo Rdečega križa na Kranjskem 238 izšolanih posvetnih sester, tečaji za bolniške strežnice pa so bili organizirani ne le v Ljubljani, Novem mestu in Krškem, ampak tudi v vseh večjih krajih. ${ }^{16} \mathrm{~V}$ monarhiji naj bi bilo po nekaterih virih angažiranih vsaj 2.500 medicinskih sester, večina zgodovinarjev pa ocenjuje, da naj bi se ta številka približala 50.000 bolnišničnim pomočnicam. ${ }^{17}$ Christa Ehrmann-Hämmerle, ena največjih strokov-

8 Podobno potrdilo so potrebovale tudi druge ženske, ki so se zaposlile kot vojaška pomožna sila (v administraciji, kot tehnična pomoč, perice, kuharice, laborantke). Glej tudi: „Ženske pomožne moči pri armadi, «Štajerc, 4. 11. 1917, 6-7.

9 Državni zakonik za kraljevine in dežele, zastopane v državnem zboru, 2. 7. 1914, 142.

10 "Za strežniško šolo v kranjski deželni bolnišnici,« Slovenec, 6. 2. 1914, 2.

11 »I. Tečaj bolniških strežnic,« Slovenska gospodinja, 16. 1. 1913, 5.

12 Šuštar, »Od strežniških tečajev, «36.

13 „Pozor babice!, « Gorenjec, 27. 3. 1914, 3.

14 Anton Bonaventura Jeglič, Dnevnik (tipkopis), 878.

15 Hämmerle, "Mentally broken, « 91.

16 "Deželno in gospejno društvo Rdečega križa za Kranjsko, « Slovenski narod, 7. 4. 1917, 9.

17 Franziska Salm-Reifferscheidt, "Frauen in der Kriegskrankenpflege, "94. Skromna številka 2.500 medicinskih sester je omenjena $\mathrm{v}$ pismih, ki so bila poslana vodji sanitetnega osebja v vojaškem poveljstvu. 
njakinj za prvo svetovno vojno, sklepa, da naj bi bilo v vojaški službi v letu 1917 med 33.000 in 50.000 žensk. ${ }^{18}$ Poročila ministra za vojaške zadeve za leto 1917 pa je navajalo 7.000 sester in 15.000 strežnic. $^{19}$

Pojav bolniške sestre, še zlasti v primeru, če je bila ta oblečena v uniformo ženskih pomožnih vojaških sil, je že takoj ob začetku vojne sprožil nemalo začudenja tudi med ljubljanskimi meščani. Fran Milčinski je v svojem obsežnem dnevniku takoj omenil tovrstno kurioziteto, saj da je "zjutraj videl v Dolenčevi prodajalni dve ženski $v$ vojaški uniformi. ${ }^{20}$ Pojav medicinskih sester je bil nekaj izrednega, "preveč modernega", in od tu je bil le še korak do povezave s sumom, ki se je dotikal tudi vprašljive morale. Milčinski je v nadaljevanju vojnega dnevnika omenil "dve ženski«(vojni sestri), ki da "sta pri dedu v stanovanju, štabni zdravnik jima je prepustil sobo. Tičici. Imata hlače pod krilom. «1

\section{Diskurz in podoba}

Vojaška propaganda je sicer slavila bolniške sestre, saj so opravljale poklic, ki se je družbi zdel še kako prikladen za nežno in požrtvovalno naravo ženske. V slovenskih časopisih najdemo številne zapise, da "strežniško poslovanje zahteva potrebo izobrazbe in plemenito srce in $v$ to ni nikdo tako zelo poklican, kakor ženski spol.. ${ }^{22}$ Bolniške sestre je patriotski diskurz simbolno postavil ob bok moškemu - vojaku, saj naj bi tudi ženske bile pripravljene na žrtvovanje v vojni. Tako so bile poklicane, »...da pomaga[jo] ranjencem, da nastopi[jo] službo samaritanke. Ves dan in vso noč je treba biti včasih na nogah in vedno mora biti nasmeh ljubezni, da ne čuti ranjenec v prijazni okolici tako svojih bolečin. Žene, vajene le največjih udobnosti, morajo pogrešati nakrat skoraj vse, žene, vajene le sladkega brezdelja, morajo delati nakrat noč in dan, žene vajene le prijetnosti morajo opravljati nakrat težke in neprijetne posle. In vendar ni nikjer nezadovoljnosti, kljub vsemu se ji smehlja obraz. Tudi ona je junakinja, tudi ona je vredna družica junakov na meji.« 23 Bolniške sestre so v vojni propagandi poosebljale samaritansko ljubezen, bile so dobri angeli v času trpljenja. Hkrati pa naj bi opravljale vlogo mater, samo da so otroke nadomestili nemočni ranjenci, ki so jim bili prepuščeni v oskrbo. "Ranjenci se ne morejo niti ganiti; ravnati morajo ž njimi kakor $z$ majhnimi otroci. Za tako delo treba krepkega zdravja, velike telesne in dusevne sile ter samopožrtvovalnosti. Še domačemu bolniku je težko streči, kako pa šele tujemu. Ne poznaš njegovega značaja, ne njegovih želja. «"

Vendar pa so se kmalu začeli pojavljati dvomi in kritike, povezani z vstopom žen-

18 Christa Hämmerle, Heimat/Front. Geschlechtergeschichteln des Ersten Weltkrieges in ÖsterreichUngarn (Wien, Köln, Weimar: Böhlau Verlag, 2014), 21.

19 "Državni zbor,«Slovenski gospodar, 13. 12. 1917, 3.

20 Fran Milčinski, Dnevnik 1914-1920 (Ljubljana: Slovenska Matica, 2000), 111.

21 Ibid., 111-112.

22 "Strežniška šola v deželni bolnišnici,« Slovenec, 7. 1. 1914, 2.

23 "Junaki,« Soča, 28. 8. 1914, 9.

24 "Ženske in vojna," Tedenske slike, 28. 10. 1914, 2. 
sk v ta poklic. Dunajski psiholog Wilhelm Stekel je v medicinskih sestrah prepoznal narcistični tip človeka, ki da so se zaljubljene vase odločile za avanturizem. Izkušnje vojne in druženje z ranjenci, oficirji ter zdravniki naj bi ženske močno spremenili. Milčinski je to spremembo opazil tudi pri eni izmed svojih sorodnic, ki naj bi se po odhodu na fronto vrnila močno spremenjena. "Zvečer prišla Hermina na obisk, vojna sestra. 28 let stara, pa izgleda 40. Močna, degažirana. Neženantnemu govorjenju se pozna občevanje z zdravniki. Dovtipe pripoveduje, da bi bilo treba pri njih ven iti. 25 Kako zelo sumljive so se prebivalstvu zdele vojne sestre, potrjuje tudi njena nadaljnja izpoved, ${ }^{26}$ kjer je Milčinskemu zaupala, kako je bila sprejeta v vojaški utrdbi v Puli (to je bila izkušnja, zaradi katere je kasneje ta poklic tudi zapustila). »Vojne sestre« so bile nastanjene $\mathrm{v}$ starem samostanu, pred tem pa so bile zaradi aprovizacijskih težav iz mesta izgnane prostitutke. Z njihovo nastavitvijo so se po mestu začeli širiti glasovi, češ da "zdaj pridejo v uniformah nazaj", 27 oziroma pojavil se je "naval mornarjev po ulici, ker so čuli, da je dospelo 'sveže blago'. "28 V Puli naj bi bile brez resnega dela, morale so ribati tla, Hermina kot nadsestra naj bi bila postavljena pod »komando nune«, glede prehrane naj bi jim podčastnik obljubil, da bodo zjutraj »dobile črno kavo, opoldan fižol s polento ali polento s fižolom in zvečer črno kavo, in če boste z menoj zelo ljubeznive morda še kakšen zrezek. "29

$\mathrm{V}$ marsikaterem zapisu izpod moške roke je ženska pomoč zdravstvenemu osebju prikazana tudi kot "nekoristna«. Tovrstna oznaka je verjetno povezana z začetkom vojne, ko se je angažiralo v Rdečem križu veliko število prostovoljk, ki jih je nato zamenjala plačana medicinska pomoč. ${ }^{30}$ Delo prostovoljke je v začetku vojne pogosto spremljalo veliko skepticizma, Evgen Lampe je denimo ugotavljal, da "dame, $k i$ pridejo $k$ sprejemu ranjencev, so bolj na poti kot za pomoč. «31 V začetku vojne je bilo med prostovoljkami zlasti veliko plemkinj in bogatih meščank, ki naj bi v nekaterih primerih izgubile stik z realnostjo. (Eno izmed takih prigod opisuje pod oznako "resničen dogodek " tudi Leopold Lenard.) "Dobiti je morala stanovanje, obstoječe iz dveh, lepih sob, za svojo postrežbo dva vojaka, avtomobil na razpolago, kadar je zahtevala in še mnogo drugega. Njeno delovanje je pa obstojalo v tem, da je bolnike 'krepčala.' $V$ kuhinji je zapovedala narediti šato in napeči piškotov. S to robo je šla potem okrog bolnikov, pri njej dva vojaka, prvi je vlival bolniku z Žličko šato v usta, drugi je nosil košarico s piškoti. Grofica stopi k postelji, kjer je ležal na tifusu težko bolni Bošnjak ter ga nagovori: 'No, Kerl, kako gre?' Rekla je namreč vsakemu 'ti' in 'Kerl.' Bošnjak samo stoče in ne odvrne ničesar, prvič, ker je ni razumel, drugič, ker je vsled bolezni bil v nezavesti. 'Kako neumen je ta Kerl!' zakliče grofica ter pomigne vojaku, naj mu vlije zžličko v usta,

25 Milčinski, Dnevnik, 139.

26 Po vsej verjetnosti gre za Hermino Tischler iz Velenja, hčerko sestrične F. Milčinskega.

27 Milčinski, Dnevnik, 248.

28 Ibid., 268.

29 Ibid., 248.

30 Hämmerle, "Mentally broken, « 93.

31 Evgen Lampe, Dnevniški zapiski dr. Evgena Lampeta: (1898-1917), ur. Matjaž Ambrožič (Ljubljana: Arhivsko društvo Slovenije, 2007), 57. 
šato, a sama pa vzame piškotek in ga položi na vzglavje. - Tako je obiskovala bolnike, kadar se ji je zazdelo, bolnišnica je imela od tega samo škodo, bolniki pa nobene koristi. «22

Vendarle pa se je ženski prispevek k zdravstveni oskrbi v javnem diskurzu v glavnem minimaliziral z nadaljevanjem diskurza o moralno sumljivih vojnih sestrah. V spominih marsikaterega vojaka vojne sestre nastopajo kot popolno nasprotje dobrega angela, kot "padli angeli.» Mednje zagotovo sodi dogodek, ki ga je v svojem dnevniku opisal Albin Mlakar, "pa to naj še bo, nekaj druzega je, kar me je tako jezilo, da bi bil najraje odšel in zaloputnil za seboj vrata. Prišli sta namreč dve 'sestri' od rdečega križa. Sestre - tudi drugače jim pravijo. In zabavali so se tam celo uro, mi smo pa stali tam kakor svetniki. Njih obnašanje jih je pokazalo v pravi luči. S takimi 'sestrami' ni vojakom nič pomagano. " ${ }^{33}$ Vojake je v času bivanja v bolnišnicah razburjalo marsikaj, zlasti pa neodvisnost in občasna friviolnost medicinskih sester, tudi Januš Golec se je v "onih mesecih v Miskolczu [...] jezil na Mažare in na žensko postrežbo v vojaških bolnicah. Vpočetku vojne je bilo v tem oziru bolje, ker je bilo še dosti prostovoljnih sester Rdečega križa, za mojega premetavanja po bolniški postelji so bile že izginile prostovoljke, nadomestile so jih plačane. Svetlikali so se jim na pokrivalu, na prsih in roki blesteči rdeči križi, vendar v srcu jim je počival mesto križano ljubezni-kamen. Ženska je pač-ženska. Zagleda se v enega, temu bi postregla z vsem mogočem - drugemu pa ponudi samo najpotrebnejse in še to a neusmiljeno osornostjo. Mene ni marala nobena, a zato sem pa bil tudi revež na zabavi in želodcu. «34

K njihovemu dvomljivemu slovesu je poleg spominov verjetno pripomoglo tudi leposlovje, medicinske sestre so namreč $\mathrm{v}$ različnih romanih, ki so izhajali v podlistkih tudi v slovenskem časopisju, nastopale kot glavne akterke romanc. ${ }^{35}$ Moderna in neodvisna medicinska sestra, ki je bila daleč proč od nadzora družine, je utelešala sodobno žensko, ki ji romantično hotenje ni bilo tuje. Svoje želje je namreč za razliko od drugih junakinj uresničila v senci eksistencialne izkušnje vojne. V ljubezenskih

32 Leopold Lenard, »Sestra 'Rdečega križa', « Slovenski gospodar, 2. 10. 1919; 25. 9. 1919.

33 Albin Mlakar, Dnevnik: 1914-1918 (Kobarid: Turistična agencija K. C. K., 1995), 99.

34 Januš Golec, »Vojni spomini, «Slovenski gospodar, 28. 2. 1918, 1.

35 Kotarski, „Usmiljenka,« Jadranka 1, št. 12 (1921), 5.

"Velimir Malnerič je stal šsiroko odprtimi očmi in gledal usmiljenko, ki je stala povešenih oči tam pri mizi, zardevajoča in tako ljubka. Ni verjel svojim očem. Zdelo se mu je, da vnovič gleda pred seboj prikazen in kakor takrat v polsnu, so šepetale njegove ustnic polne hrepenenja:

- Ivanka!... Ivanka!...

Zdravnik pa je dejal: .

- To je ona usmiljenka, gospod narednik, ki vas pospremi v Ljubljano. Upam, da se vam pod njenim varstvom in negovanjem ukrepi zdravje, kakor se vam je pod njenim požrtvovalnim trudom zacelila rana.

Zdaj se je šele narednik zganil. Stopil je naprej in vzkliknil s pol radostnim, pol plašnim glasom, kakor bi se še vedno bal, da bi ne bile sanje, kar vidi čuje:

- Ivanka....

In ona se mu nasmehne tako prijazno in milo, da je izginil ves dvom kakor pena. Nato jo je že privijal $v$ svoje naročje in jo poljubljal. Ni se mu branila. Zaprla je oči in sloneč na njegovih prsih, je drhtela sreče in šepetala:

Imam te spet, Velimir.... moj Velimir...".

Glej tudi: »Ne sodi,«Edinost, 24. 2. 1917. »Izgubljeni sin,« Domoljub, 23. 5. 1918. 
fikcijah, ki so tedaj nastale, so bile tradicionalne norme potisnjene na stran v luči nove sekularne človeške narave. In čeprav se je v zgodnjem 19. stoletju ponovno okrepila vloga tradicije in morale v družbi tudi v ljubezenskem romanu, je prva svetovna vojna vse to spremenila. Vojna je pospešila percepcijo o enakopravnosti žensk in trend sprejemanja predporočne spolnosti. ${ }^{36}$ Platonska ljubezen se je v novi dobi udejanjila $s$ kršitvijo moralnih norm. Vojne sestre pa bodo kot moralno sumljivi liki nastopale tudi v povojnih delih slovenskih pisateljev. ${ }^{37}$

Posvetne medicinske sestre po mnenju javnosti niso bile primerljive z redovnicami. Te so svoje delo opravljale kot poslanstvo in s predanostjo, ki naj bi je ne mogli srečati pri "posvetni sestri «. "Zakaj so sestre usmiljenke tako priljubljene strežnice? Zato, ker se iz ljubezni do Boga popolnoma žrtvujejo svojemu poklicu. Prelepo jih je nedavno pohvalil na Dunaju neki ranjen bosenski mohamedanski vojak. [...] Z enako ljubeznijo strežejo vsem bolnikom brez razlike vere in narodnosti. Ponoči bde in nikdar nobena ne zaspi. Imel sem mrzlico in večkrat mi je bilo treba ponoči premeniti obkladke. Sestra je vsekdar točno prišla; laška strežnica je pa vselej zaspala, kadar je sedela tu. Drugi vojaki so imeli nekoč slanino. Sestra je vedela, da jaz kot mohamedanec ne smem jesti slanine, pa mi je prinesla sirovega masla in sira. "38 Prostovoljke in plačane strežnice ter medicinske sestre naj bi si torej dovoljevale, da v njihovo delo vstopajo čustva in predsodki, poleg ljubezenskih tudi npr. politična prepričanost in narodnost. V Ljubljani naj bi denimo Nemke ne hotele streči slovanskim vojakom, Slovenke pa naj bi posebej predano skrbele ravno zanje. ${ }^{39}$

\section{Kršenje tabujev}

Medicinska sestra oziroma strežnica naj bi po zgledu redovnic ostajala aseksualna, spolno nedolžna. Toda podobo sodobne ženske, skrite v "posvetni« medicinski sestri, je bilo težko dojeti enako kot redovniško - materinsko podobo. Sodobna ženska, ki se je osvobodila kontrole družbe, je bila neodvisna s plačano službo in v neposredni bližini vojne nevarnosti po lastni želji, bila je popolnoma drugačna od neplačane, pokorne in v usodo vdane redovnice. Moderna ženska je s seboj nosila svojo ženskost, njeni pacienti se ob njej niso več počutili kot otroci, pač pa kot moški. Medicinske sestre so zamajale tudi večstoletno ustaljeno dihotomijo med moškimi in ženskami,

36 William M. Reddy, "The Rule of Love: The History of Western Romantic Love in Comparative Perspective," v: New Dangerous Liaisons, Discourses on Europe and Love in the Twentieth Century, ur. Luisa Passerini, Liliana Ellena in Alexander C.T. Geppert (New York: Berghahn Books, 2010), 46.

37 Alojz Kraigher, Na fronti sestre Žive (Ljubljana: Tiskovna zadruga, 1929).

38 "Zakaj so sestre usmiljenke tako priljubljene strežnice?," Vertec, 1. 3. 1916, 47.

39 „Dr. Triller se je pritoževal, da so njegovo ženo šikanirali, ko je v licej čěkim ranjenjcem za priboljšek prinesla buhteljnov. "Gospa Högler pa naj bi pri sprejemu na kolodvoru ranjencu, ki se ji je zahvalil, odgovorila: Windisch wird hier nicht verstehn!" Vendar pa so se z nadaljevanjem vojne polegli tudi slednji konflikti, gospa Högler je bila primorana zapustiti Rdeči križ, potem ko »je nekoč letala zopet okoli ranjencev s cigaretami in izpraševala, kje so Nemci, je naletela na nekega Čeha. Ko ji je rekel, da je Čeh, mu ni hotela dati. Nato je pristopil nek castnik, ji s sabljo odrezal trak z rdečim križem z rokava in jo zapodil." (Glej Lampe, Dnevniški zapiski, 66, 84). 
ki jo je poosebljal pasiven/aktiven status. Ženske so na bojišču namreč prevzele aktivno vlogo nasproti pasivni - moškemu/ranjencu. ${ }^{40}$

Vzrok, da se je njihovo delo tako hitro povezalo tudi s "sumljivo moralo", je zagotovo tudi to, da so pripadnice meščanskega razreda, ki so bile med medicinskem osebjem najštevilčnejše, pri svojem delu kršile predvojne tabuje, povezane z moškimi telesi. Strežnice in medicinske sestre so ob svojem delu spoznale moška telesa, pa tudi strahove ranjencev, in videle moške v najbolj intimnih in ranljivih trenutkih. ${ }^{41}$ Eno izmed takšnih situacij je, potem ko je dobil poškodbo na testisih, opisal vojni ujetnik Leopold Vadnjal. "Strežnica, mlado lepo dekle, je bridko zajokala, ko sem ji razkril rano, ne vem, ali od sramu ali od sočutja. Obstala je poleg mene in moral sem jo prositi, naj mi umije rano; prigovarjal sem ji, naj se ne sramuje, kajti jaz neznosno trpim... Ozdravel sem toliko, da sem lahko sam hodil povezovat rano v operacijsko sobo. Mlada Olga, ki je pomagala pripravljati zdravila, si je vsa zardela vedno veliko dala opraviti v kakšnem kotu, da me ni videla. Bila je zelo sramežljiva. Le stara feldšerica (zdravniška pomočnica) Natalija Vasiljevna si je pri meni dala veliko opraviti. Kljub vsem bolečinam pa je bilo vedno dosti smeha, kadar so me prevezovali. Nobena preveza ni držala, ker sem hodil in preveze niso mogli nikamor dobro zavezati. Slednjič pa jo je izkušena N. Vasiljevna le pogruntala. Sešila je majhno vrečico in napravila zadrgo z dolgimi trakovi... «42

Delo medicinskega osebja, zlasti žensk, je po prepričanju javnosti obsegalo tudi tolažbo in prijazno besedo. "Dočim ima zdravnik le bolj ozir na pojav bolezni in $v$ svojem delovanju vpošteva le telesnost, išče idealna strežnica $v$ svoji nežnočutnosti vplivati na bolnikovo notranjost. " ${ }^{43} \mathrm{~V}$ tolažbi in pogovoru je izginjala osamljenost in nastala je intimnost, ki jo v svojih spominih omenjajo vojaki. ${ }^{44}$ Iz te intimnosti se je lahko razvila ljubezen, vendar pa se je $\mathrm{v}$ vojni vihri pogosteje zgodilo ravno nasprotno. Spopadi so skrbeli za velik pritok ranjencev, medicinskemu osebju je bilo nemogoče vzpostaviti z vsakim izmed ranjencev zaželen odnos oziroma odnos, ki naj bi ga žensko medicinsko osebje zagotavljalo (tudi zato je bila verjetno razočaranost tistih, ki so občutili neosebno oskrbo, še večja). Tudi Christa Hämmerle tako omenja, kako so se medicinske sestre le redko spominjale zgodb posameznih vojakov in v svojih spominih ločile med seboj in množico ranjenih vojakov. Namesto zgodb posameznikov je v njihovem pričevanju nastopal abstraktni drugi - ranjenec. ${ }^{45}$

Med prvo svetovno vojno so bile govorice, češ da so prostovoljne oziroma posvetne sestre nagnjene $\mathrm{k}$ moralnemu padcu, zaradi zgoraj omenjenih razlogov pogoste. $\mathrm{Na}$

40 Francoise Thébaud, "The Great War and the Triumph of Sexual Divison, « v: A History of Domen in the West. Volume V. Toward a Cultural Identity in the Twentieth Century, ur. Françoise Thébaud (Cambridge: Harvard University Press, 1994), 41.

41 Darow, „French Volunteer Nursing, «275. Susan R. Grayzel, Women and the First World War (Abingdon, New York: Routledge, 2002), 41.

42 Leopold Vadnjal, Zapiski vojaka, 1914-1921, ur. Stanko Janež (Ljubljana: Borec, 1989), (75) 1308.

43 „O ženskih poklicih,«Slovenski učitelj, 15. 9. 1918, 178.

44 Vadnjal, Zapiski vojaka, 75 (1308). Dominik Kacin, "Dnevnik z avstrijsko-ruske fronte v Karpatih in spomini iz vojaške bolniške v Romuniji iz let 1917-1918, « Borec 49, št. 555/556 (1997): 33, 35.

45 Hämmerle, «Mentally broken,«99. 
Dunaju naj bi glede na govorice, ki so krožile v Ljubljani, obstajal celo dom za noseče bolniške sestre. Imel naj bi kapaciteto za 500 sester, saj naj bi bilo po javnem mnenju kar 80 odstotkov med njimi nagnjenih $\mathrm{k}$ nemoralnem vedenju. ${ }^{46}$ Vendar nekateri drugi indici namigujejo ravno nasprotno, da so bile vojne sestre v bolnišnicah pod strogim nadzorom, še zlasti glede morale. ${ }^{47}$ Toda če se v javnem diskurzu v času vojne pojavlja precej dvomov glede zglednega življenja vojnih sester, to za redovnice ne velja.

Redovnice so poleg posvetnih sester predstavljale velik korpus negovalk na vojni črti, med njimi pa so zagotovo prevladovale članice kongregacije Usmiljenk ali Hčere krščanske ljubezni. V letu 1901 je kar 65 odstotkov redovnic služilo v dobrodelnih redovih in tudi v letu 1916 ni bilo nič drugače. Na Kranjskem je bilo 634 redovnic, večino med njimi so predstavljale prav redovnice reda Usmiljenk, bilo naj bi jih $339 .{ }^{48} \mathrm{Na}$ Soški fronti so redovnice predstavljale precej večji delež kot posvetne sestre. ${ }^{49}$ Med prvo svetovno vojno naj bi jih bilo na bojiščih vsaj $10.000 .{ }^{50}$ Redovnice v diskurzu, ki opisuje razmere med prvo svetovno vojno, ostajajo cenjene, toda fragmenti nakazujejo, da tudi te niso bile povsem izvzete iz skušnjav, ki jih je fronta ponujala bolniškim sestram. Tudi nečakinja škofa Jegliča se je tako znašla v moralni skušnjavi, kateri je podlegla. "Dne 22/6 ravno na praznik sv.R.T. je moja nečakinja S. Lavrentina skrivaj zapustila svoj samostan v Sarajevu in izginila. Ker je posebej pri bolnikih mnogo delala, so jo povsod izredno spoštovali in cenili: zato v Sarajevu splošno presenečenje. Začetek njenega padca je v Tuzli pred dobrima dvema letoma. Bila je sama v bolnišnici; zapeljeval jo je ondotni zdravnik in še nek bolnik. Nadlegovali so jo ponoči, ko je morala ležati na hodniku, branila se je in ohranila usque ad copulum ni prišlo. Toda od tega časa ji je spolna strast strašno vzplamtela; njen spovednik (p.Jošt) je bil prepričan, da so ji v jed dajali sredstva, po katerih se mesenost strašno vzpodbudi. $V$ obupanosti bi bila najrajše umrla, $v$ hudi zimi je napol oblečena stala ponoči pri odprtem oknu, da bi se prehladila in umrla. Koj potem mi piše iz Sarajeva obupen list. Ne vedoc kaj je pravzprav, pišem da pridem osebno $v$ Sarajevo in sicer na sv.Jožefa čestitat nadškofu za god. Povedala mi je, da ima obleko posvetno že pripravljeno in je hotela pogniti skrivoma. Pomiril sem jo. - Odkar je vojska je vedno po bolnišnicah, vsem priljubljena. Večkrat mi je vlistih omenila 'Ich bin nicht brav. 'Zato sem o mojem godu prosil glavno predstojnico na Dunaju, naj jo odpokliče v samostan. Toda s. Lavrentina noče na Dunaj, ampak pobegne skrivaj. «51

46 Milčinski, Dnevnik, 140. Več o zaščiti otrok pred in med vojno glej: Ana Cergol Paradiž, "The Protection of Mothers and Children as a Eugenic Measure in Ljubljana, «Revista de Antropologie Urbana 3, št. 5 (2015).

47 NŠAL, vizitacije (1914-1916), šk. 14, mapa ŠAL/VIZ map. 1916 (1-55). Spomenica Sava, »V župniji imamo od okt. 1915 bolnišnico Rd.Kr. v ponoviški graščini. ... V graščini pazi pa grofica de Gosquet precej strogo na moralno življenje postrežnic in zažuga vsaki odpustitev iz službe, ki se noče pokorit. Posebnih prestopkov se doslej ni zgodilo."

48 „Catalogus Cleri, Učiteljski tovarǐ̌, 24. 3. 1916, 4.

49 "Zdravstvene razmere na soški in jugovzhodni fronti,« Slovenec, 15. 3. 1917, 3.

50 „Čez 10.000 usmiljenih sester na bojiščih, «Slovenec, 20. 2. 1915, 7.

51 Jeglič, Dnevnik, 1034. 


\section{Zaključek}

Vélika vojna je dramatično spremenila položaj žensk, predvsem so ženske v teh izrednih razmerah prerastle svojo tradicionalno vlogo, povezano s čakanjem $\mathrm{v}$ zaledju, molitvijo in žalovanjem. Nekatere med njimi so namreč oblekle uniformo in se podale v samo osrčje nevarnosti. Žal je ostalo za njihovim delovanjem malo sledi, spomini žensk na prvo vojno so redki, v večini je prevladal moški pogled nanjo. Če primerjamo dogodke prve svetovne vojne $\mathrm{z}$ drugo, so $\mathrm{v}$ drugi vojni ženski glasovi $\mathrm{v}$ pričevanjih pogostejši. V tej vojni nastopajo kot herojke, pogumne partizanke, interniranke in bolničarke. $\mathrm{V}$ spominu na prvo svetovno vojno pa je vendarle prevladala izkušnja vojaka, in kot pravi Fussel, je ta v večini ostala bipolarna. Vojaki v jarkih so dojemali svet črno-belo, slednjo percepcijo najbolje ponazarja delitev med "nas in sovražnike«. Iz tega razumevanja realnosti pa niso bile izvzete ženske. ${ }^{52}$ Te so pravzaprav bile predmet kar dveh dihotomij. Sprva se je oblikovala delitev med vojake in ženske, nato pa so ženske doživele še drugo oznako: ali so bile trpeče žrtve ali pa moralno padle ženske.

Bolničarke oziroma ženske na fronti so prestopile meje, ki jih je zakoličila predvojna era in so vsekakor pomenile motnjo v vsakdanu. Že zato jim je javnost pripisala nemoralnost. Bile so neodvisne, plačane, daleč stran od družinskega nadzora. Redno so prihajale v stik z moškimi, padali so predvojni tabuji, povezani s telesom. Hkrati pa so le redki ranjenci od medicinskih sester dobili pričakovano emocionalno podporo in zato bili seveda globoko razočarani. Prav ženske naj bi namreč s svojimi junaškimi dejanji na fronti zaščitili, te pa naj bi jim zagotovile uteho in tolažbo. Prva svetovna vojna je razbijala tudi utečena pričakovanja glede razmerij med moškimi in ženskami. Medicinske sestre so v romantičnem leposlovju nastopale kot nosilke modernosti, kršile so namreč prepovedi, povezane z ljubezenskimi razmerji, in se jim predale. Ob vseh ugotovitvah pa velja dodati, da slednji prispevek predvsem razodeva pogled drugih na "vojaške sestre«, kako so same razumele svoja dejanja in se odzivale na svoj položaj, ostaja odprto. Njihovi slovenski spomini še čakajo na odkritje, da izvemo, ali je bil motiv Marianne Jarka (upanje, da bi jo videl »ljubljeni Fredl«) ${ }^{53}$ pogost ali ne.

\section{Viri in literatura}

Arhivski viri:

- NŠAL, Nadškofijski arhiv Ljubljana:

o Vizitacije (1914-1916).

Časopisni viri:

- "Catalogus Cleri.« Učiteljski tovariš, 24. 3. 1916.

- „Čez 10.000 usmiljenih sester na bojiščih.« Slovenec, 20. 2. 1915.

52 Mary Louis Roberts, Civilization Without Sexes: Reconstructing Gender in Postwar France, 1917-1927 (Chicago: University of Chicago Press, 1994), 21.

53 Franziska Salm-Reifferscheidt, „Frauen in der Kriegskrankenpflege," 23. 
- "Deželno in gospejno društvo Rdečega križa za Kranjsko.« Slovenski narod, 7. 4. 1917.

- "Državni zbor.« Slovenski gospodar, 13. 12. 1917.

- Golec, Januš. „Vojni spomini.«Slovenski gospodar, 28. 2. 1918.

- "Izgubljeni sin.« Domoljub, 23. 5. 1918.

- "Junaki.«Soča, 28. 8. 1914.

- Kotarski. »Usmiljenka."Jadranka 1, št. 12 (1921), 2-5.

- Lenard, Leopold. „Sestra 'Rdečega križa'.«Slovenski gospodar, 2. 10. 1919; 25. 9. 1919.

- $\quad$ "Ne sodi.«Edinost, 24. 2. 1917.

- „O ženskih poklicih.«Slovenski učitelj, 15. 9. 1918.

- "Poročilo o dekanskem shodu leta 1908.«Škofijski list, št. 5 (1908), 69-86.

- "Pozor babice!.« Gorenjec, 27. 3. 1914.

- "Strežniška šola v deželni bolnišnici.« Slovenec, 7. 1. 1914.

- " "Tečaj bolniških strežnic."Slovenska gospodinja, 16. 1. 1913.

- "Za strežniško šolo v kranjski deželni bolnišnici.« Slovenec, 6. 2. 1914.

- "Zakaj so sestre usmiljenke tako priljubljene strežnice?.»Vertec, 1. 3. 1916.

- "Zdravstvene razmere na soški in jugovzhodni fronti.«Slovenec, 15. 3. 1917.

- "Ženske in vojna." Tedenske slike, 28. 10. 1914.

- "Ženske pomožne moči pri armadi.« Štajerc, 4. 11. 1917.

\section{Literatura:}

- Cergol Paradiž, Ana. »The Protection of Mothers and Children as a Eugenic Measure in Ljubljana.» Revista de Antropologie Urbana 3, št. 5 (2015): 54-62.

- Darow, Margaret H. „French Volunteer Nursing and the Myth of War Experiance in World War I.» American Historical Review 101, št. 1 (1996): 80-106.

- Grayzel, Susan R. Women and the First World War. Abingdon, New York: Routledge, 2002.

- Hämmerle, Christa. »'Mentally broken, physically a wreck...': Violence in War Accounts of Nurses in Austro-Hungarian Service." V: Gender and the First World War, ur. Christa Hämmerle, Oswald Überegger in Birgitta Bader-Zaar, 89-107. Basingstoke: Palgrave Macmillan, 2014.

- Hämmerle, Christa. Heimat/Front. Geschlechtergeschichteln des Ersten Weltkrieges in Österreich-Ungarn. Wien, Köln, Weimar: Böhlau Verlag, 2014.

- Rachamimov, Alon. »'Female Generals' and 'Siberian Angels': Aristocratic Nurses and the AustroHungarian POW Relief." V: Gender and War in Twentieth-Century Eastern Europe, ur. Nancy M. Wingfield in Maria Bucur, 23-46. Bloomington: Indiana University Press, 2006.

- Reddy, William M. »The Rule of Love: The History of Western Romantic Love in Comparative Perspective." V: New Dangerous Liaisons, Discourses on Europe and Love in the Twentieth Century, ur. Luisa Passerini, Liliana Ellena in Alexander C.T. Geppert, 33-57. New York: Berghahn Books, 2010.

- Roberts, Mary Louis. Civilization Without Sexes: Reconstructing Gender in Postwar France, 1917-1927. Chicago: University of Chicago Press, 1994.

- Salm-Reifferscheidt, Franziska. »Frauen in der Kriegskrankenpflege im Ersten Weltkrieg am Beispiel der Rotkreuzschwester Marianne Jarka.« Diplomsko delo, Universität Wien, 2010. http://othes. univie.ac.at/8208/.

- Šuštar, Branko. „Od strežniških tečajev do strežniške in bolničarske šole 1908-1945.« V: Šola za sestre: Zdravstveno šolstvo na Slovenskem (1753-1992), ur. Branko Šuštar, 35-41. Ljubljana: Slovenski šolski muzej, 1992.

- Thébaud, Francoise. "The Great War and the Triumph of Sexual Divison."V: A History of Domen in the West. Volume V. Toward a Cultural Identity in the Twentieth Century, ur. Françoise Thébaud, 21-75. Cambridge: Harvard University Press, 1994.

- Zeldin, Theodor. An intimate history of Humanity. London: Vintage Books, 1998.

Objavljeni viri:

- Jeglič, Anton Bonaventura. Dnevnik (tipkopis). 
- Kacin, Dominik. „Dnevnik z avstrijsko-ruske fronte v Karpatih in spomini iz vojaške bolniške v Romuniji iz let 1917-1918.« Borec 49, št. 555/556 (1997): 23-60.

- Lampe, Evgen. Dnevniški zapiski dr. Evgena Lampeta: (1898-1917). Ur. Matjaž Ambrožič. Ljubljana: Arhivsko društvo Slovenije, 2007.

- Milčinski, Fran. Dnevnik 1914-1920. Ljubljana: Slovenska matica, 2000.

- Mlakar, Albin. Dnevnik: 1914-1918. Kobarid: Turistična agencija K. C. K., 1995.

- Vadnjal, Leopold. Zapiski vojaka, 1914-1921. Ur. Stanko Janež. Ljubljana: Borec, 1989.

Tiskani viri:

- Državni zakonik za kraljevine in dežele, zastopane v državnem zboru. Dunaj: c. kr. dvorna in državna tiskarna, 1914.

Irena Selišnik

HEALTH CARE IN THE SERVICE OF WAR: WAR NURSES IN CARNIOLA

S UMMARY

Even before World War I an ongoing discussion took place in Austria whether medical nurses should be mobilised to take care for wounded soldiers in case of extensive military conflict, natural disasters or epidemics. After the outbreak of the Great War the Austrian authorities encouraged the professionalisation of nursing, and especially women were invited to join. Special conditions for schooling were enacted and the first courses were opened at local hospitals. In the Austrian Monarchy, Carniola was no exception. The Red Cross organised special courses for nurses with the promise of salary, retirement benefits and possibility of vacation. In 1917 we can already find 7000 nurses and 15,000 care attendants among the Austrian military personnel. The Austrian propaganda portrayed war nurses as heroines, and at least part of the public perceived them as a personification of motherly care and love which could be compared with the sacrifices of the soldiers. However, war nurses also represented modern women who successfully avoided social control headed towards imminent danger in the battlefield. The attempts to present them as nurses from religious orders failed. Because professional nurses were paid and were therefore much more independent, they represented a strong contrast to the submissive and ethereal motherly image of nuns. Quite unsurprisingly, their obvious womanhood resulted in the emergence of doubts about their morality. Nurses had direct contact with soldiers, they cared for their wounded bodies, and all the established taboos about middle-class women therefore disappeared. Furthermore, because the flow of the wounded from the front was enormous, they could not live up to their image as presented by the war propaganda and provide emotional support for each wounded soldier. The disillusioned soldiers were especially critical of the nurses also because actual nurses could not compare to their fictitious character as described in romantic fiction. The concepts of romantic love quickly changed during the war, as modern women embodied by the nurses were not afraid of love and platonic relationships were also consumed. In combination with the soldiers' perception of reality in dichotomous concepts like "us and women", "fallen women and victimised women", etc., the image of nurses was accompanied by strong discomfort. The image of war nurses clearly reveals the awkward relationships between the attitudes to war and women and as well as the rapidly changing values in time of war. 